\title{
PCrowdsourcing in Public Policy: Technologies, Subjects and Its Socio-Political Role
}

\author{
Elena Vasilievna Morozova ${ }^{1}$ \\ ${ }^{1}$ Inna Valerievna Miroshnichenko, Kuban State University, Russia \\ Correspondence: Elena Vasilievna Morozova, Inna Valerievna Miroshnichenko, Kuban State University, ul. \\ Stavropolskaya 149, Krasnodar, 350040, Russia. E-mail: morozova_e@inbox.ru
}

Received: October 25, 2014 Accepted: December 13, 2014 Online Published: March 16, 2015

doi:10.5539/ass.v11n7p111 URL: http://dx.doi.org/10.5539/ass.v11n7p111

\begin{abstract}
The article describes the potential of the new interactive crowdsourcing technologies in the public policy. The conceptual basis of the research implies the network theory of policy, the theory of deliberate democracy and the concept "governance". The empirical study was based on the methodology of double reflexivity and conducted using such tools as case study, focus-group interview and monitoring of the online platforms of Russian and foreign crowdsourcing resources. The authors emphasize and characterize the main technologies of political crowdsourcing: prediction market crowdsourcing, network brainstorming, project crowdsourcing, and crowdfunding. The authors think that the socio-political role of crowdsourcing lies in the extension of space in which the authorities and citizens interact, the initiation and introduction of political innovations, and the development of the new forms of civil and political participation.
\end{abstract}

Keywords: public policy, crowdsourcing, interactive technology, network communities

\section{Introduction}

Crowdsourcing is an innovative and interactive mechanism of the interaction between authorities and citizens which technologies and resources have developed in the public policy of the modern states. The American economist E. von Hippel considers crowdsourcing to be an innovation aimed at a user when the certain operational functions are transferred to an uncertain circle of persons by a public offer, not meaning the conclusion of an employment contract (Crowdsourcing, 2014).

Crowdsourcing has its roots in the base egalitarian principle: each person has knowledge and talents which other people may need. On the Internet, the crowdsourcing activity involves the creation of network communities, allowing to use the "policy of diversity" of the network individual actors to design and implement collective ideas or projects.

The term "crowdsourcing" was introduced by the writer Jeff Howe and Mark Robinson, the editor of the journal Wired to describe the business model that is based on the attraction of consumers, Internet users and volunteers for the production and distribution of products and services, and generation of ideas and solutions (Howe, 2012). In terms of interdisciplinarity, crowdsourcing is defined as a complex of solutions, generated by the attraction of intellectual, informational and organizational efforts of the open network community (Geerts, 2009).

The peculiarities of crowdsourcing technology using in the public policy consist in that the government authorities (contrary to economic subjects) rely on the users not only in the formulation of needs, but also in the determination of the effective management techniques which would serve these needs. Rephrasing E. von Hippel, it can be said that this trend was created expecting that citizens will want to share their ideas with the authorities for free or a reasonable payment only to see their ideas are implemented in the public policy.

\section{Theoretical Basis of the Research}

The conceptual basis for the research of the crowdsourcing development processes and the results of their effect on the public policy is the concept of the network society by M. Castells (Castells, 1999; Castells, 2000) who defines it as a resultant vector of the information ecosystem development where knowledge and information flows play the defining role. In the information society, social communication, transforming institutes and practices, gets absolutely new network qualities of a universal nature. 
The network theory of the politics substantiated by E. Klijn and J. Koppenjan in their works (Klijn \& Koppenjan, 2000), conceptually combines the characteristics of political networks, the network components of political process considered as a process of policy design, and the characteristics of network management. The theory of deliberate democracy developed by J. Habermas, B. Ackerman, S. Benhabib, J. Dryzek, has the fundamental significance for the substantiation of the crowdsourcing importance in the politics. The essence of the deliberate democracy theory means that the modern state actively engages the institutes of the civil society, the democratic community, and the community of experts in the cooperation to get the approval of the society and make joint political decisions under relative transparency. By reference to the above mentioned theory, crowdsourcing can be considered as a resource of the modern public management.

The theoretical origin of the network management is the concept of governance as a result of critical understanding of "new public management" (Bevir, Rhodes, \& Weller, 2003). Then, the elaboration of the theory of the network public management contributed to the substantiation of the network theory of policy which interprets the different roles of network components in the elaboration and implementation of public policy (Pierre, 2000; Damgaard, 2005).

The studies of the network structures of the civil society and their constructive potential in the sphere of the public policy based on the theoretical tradition of R. Puthnam, F. Fukuyama (Fukuyama, 2008; Puthnam, 1996), etc. and described in the manuscripts by R. Rose, S. V. Patrushev, T. V. Pavlova, L. Gudkov, G. Gradoselskaya, E. Petrenko, O. Oberemko, A. Khlopin, etc. (Rose, 2002; Patrushev, 2009) represent a special trend.

The developing scientific direction within the network approach is research studying the online space and its role in the change of the public policy format both in global (Hacker and Dijk, 2000; Ryabchenko, 2012; Morozova \& Miroshnichenko, 2009) and national contexts associated with the appearance of the new online network structures and the interactive mechanisms of the network public management.

As for the phenomenon of crowdsourcing, the scientists have rather recently focused on it. The pioneers in the crowdsourcing research are economists, and that is quite natural, as in fact, the crowdsourcing technologies were first used by the subjects of economic activity. Crowdsourcing was treated in terms of innovative development of business and territories (Brabham, 2008) but as a new form of labour exploitation in the works of scientists, developing the neo-Marxian tradition. In social studies (Wexler, 2011), crowdsourcing is evaluated in the context of the "smart crowd" approach. I. V. Miroshnichenko, S. V. Ponomareva, A. V. Sokolov and A. A. Dementiev (Miroshnichenko, 2011; Miroshnichenko, 2012) devoted their works to political crowdsourcing. It is especially worth to mention G. Asmolov's research (Asmolov, 2014). G. Asmolov pays attention to the crowdsourcing resources, participants' motivation and trends of the technology development, evaluating in general crowdsourcing projects as a form of social mediation.

The conceptual framework of the conducted empirical studies was based on the methodology of double reflexivity. Its basis involves the combination of a theory, a qualitative strategy and the style of collective research; in the course of research, particular aspects of the methodology were examined, changed and advanced further. From the sociological methods of information gathering, case study, interactive qualitative analysis of online resources, online gathering and analysis of sociological information were used. The analysis of the empirical data was based on the qualitative strategy. The integrated data base of sources of some independent empirical studies includes materials of 40 case studies of social networks (using depth interviews, documents, materials of print and electronic mass media describing the institutionalized network activity forms, results of online information gathering in social networks, etc.), scripts of six focus group interviews with the representatives of the regional and local elite as well as with the leaders of cross-sectoral partnership in the Krasnodar Region (Russian: Krasnodarskiy Kray), online platforms of foreign and Russian crowdsourcing resources of various activity subjects: authorities, organizational structures of the civil society (traditional non-commercial organizations and networks) and social networks.

\section{Crowdsourcing Technologies in Public Policy}

Crowdsourcing of public policy originated from the network communities. Within the network communities of the citizens, crowdsourcing activity gets several technological forms: prediction market, crowdcasting (solving of certain problems by the communication on the network), network brainstorming (collision of ideas), project crowdsourcing, and crowdfunding.

Crowdsourcing as a "prediction market" refers to the activity aimed at buying the information on the future dealing with the expected results by the investor who members of social networks are. For example, the best analysis outcomes were obtained before the presidential election in the USA in 2008 not by traditional opinion 
polls and expert reviews but from the diagrams, showing "value" of the candidates at the futures market Intrade (Howe, 2012).

Crowdcasting enables the development of the solutions aimed at the certain public problems by means of the resources (intellectual, informational, organizational, etc.) of the participants from social networks. The information program "Ushahidi" ("Witness"), established in 2007 in Kenya is a bright example of using such crowdsourcing form. During the presidential election, the armed inter-ethnic conflicts between the supporters and opponents of the president M. Kibaki swept across the country. The authorities blocked the activity of many mass media therefore the citizens found themselves in the information vacuum which several bloggers tried to eliminate. One of the bloggers, Ori Okolo, asked the citizens to send messages on the events occurring around them. The information flow was systematized by the program which was named "Ushahidi" later. Currently, "Ushahidi" is a system of information management enabling to process the messages from different sources (from bloggers, mass media, and international observers) and post all obtained data on the Internet as a map on which each event is linked with the certain geographical point ("Ushakhidi" spasaet lyudey..., 2010).

For last years, political crowdsourcing has proved its efficiency in the emergency conditions. The Japanese created the crowdsourcing resource to collect data on the radiation background in the different regions of the country. The Americans integrated social networks into the process of the prevention and response of emergency situations of different kinds (Goodwin, 2010), etc.

Crowdsourcing as a network brainstorming represents the brain storm of social network participants for the generation of different ideas on the certain problem. The example of network brainstorming is a network "WhiteHouse2.org", created by J. Gilliam, the former supporter of B. Obama, which had 8600 users in June 2009. The citizens could express their support to the political requirements made by other citizens, reject them, evaluate them, comment or repost them. The users can offer the most different topics: from tax concessions and reforms in the public health services up to the investments into renewable energy sources. The more digital signatures a requirement collected, the higher it appears in the rating on the web-site of the organization.

Project crowdsourcing is a constantly running information resource, which content is provided by the public network of the non-indifferent citizens and experts, being interested in the permanent running of the resource, who are consumers and authors of the content at the same time. The implementation of the public network projects which were called "digital cities" has started in the USA and the European countries in the 1990s. For example, the project "International City of Berlin" has become a classical public network initiated by people of art, experts on computer technologies, scientists and citizens who supported the service of the "digital city" at their own expense. The project was aimed at the creation of a positive image of the city as a cultural center of Europe. Many private initiatives which have become remarkable milestones in the cultural life of Berlin were implemented thanks to the project (Bondarenko, 2004).

The public networks created by use of interactive technologies have changed into the innovative tool of positioning and servicing of local communities' interests, expanding the sense and format of the citizens' public activity. Project crowdsourcing is based on the "growing" of strong network community which members are people, deeply and seriously adhered to the business and to each other. As crowdsourcing avoids traditional financial forms of compensation, the social environment creates a context for creative work: the best ideas which do not depend on the form of their expression enable the advancement of the actors' statuses.

Crowdfunding involves the application of network technologies for fund raising to implement different purposes. Crowdfunding is mostly used in the election campaigns of different levels. At the same time, it is also used in the activity of non-commercial organizations to implement civil initiatives. So, one of the businessmen Ilia Feigenov has started the crowdfunding campaign under the auspices of the Expertise Center "Probook.net" to install the banners, which make fun of bad-mannered drivers, in City of Krasnodar in 2014. The collected money will be spent on the printing of the banners and the rent of billboards. (Krasnodarets nameren zapustit' kampaniyu ..., 2014).

Currently, crowdsourcing initiatives can be originated both directly by network communities and organizational structures of the civil society and authorities of the different levels. In such a case, the source of innovative ideas and solutions is citizens.

\section{Subjects of Political Crowdsourcing}

Depending on the subject of the initiative of the crowdsourcing organization, a certain type of online-platform on which the collective activity will be carried out is created. The traditional and network organizational structures 
of the civil society offer crowdsourcing projects which aid to form horizontal relations in the non-state sector of the public policy.

The crowdsourcing project "RosPil" (rospil.info) launched in December 2011 is an example of the actualization of network communities' subjectness in the anticorruption activity. The project purpose is to control the expenditure of the budgetary funds in sphere of state and municipal purchases. The scheme of the project work comprises as follows: At the first stage, the project participants find out the supposed corruption purchasing competitions (as a rule, on the official portal of state purchases). At the second stage, the professional experts estimate the competitions in terms of corruption. At the third stage, the legal advisers providing legal support of the project write and submit the complaints to the supervising bodies reasoning from the expert reports, (first of all to the Federal Antimonopoly Service) with the purpose to cancel corruptive purchases. In May 2012, "RosPil" made a statement on the detected frauds of 4.5 billion rubles. The project legal advisers submitted 108 complaints to the Federal Antimonopoly Service of the Russian Federation, 68 of which were acknowledged to be proved. In April 2011, the project took a prize of the international contest of blogs and network communities "The BOBs", nominated as "The most useful resource for the society".

The initiative of "RosPil" experience sharing was supported by D. Medvedev: "The foundation of the additional state supervising bodies in the system of state purchasing hardly will positively effect the transparency and publicity, and this criterion is the basic important element in the resistance to corruption. For sure, it is inefficiently to create one more bee that will work against honey. It is necessary to combat it by means of publicity and public control. In particular, the web-site "RosPil" shows how one can do it" ("Sozdavat' eshche odnu pchelu ..., 2011).

The new public structures striving to introduce "the culture of the creation of civil online applications" into the Russian public practice have become an important vector in the promotion of the crowdsourcing activity. For example, the public educational project "Greenhouse of Social Technologies" is oriented on the development of the cooperation between the non-commercial sector and IT-experts. The project has the following aims: establishment of contacts, development of cooperation and creation of the partnership relations between programmers and civil activists; design of innovative network applications for the citizens' participation and the solving of public problems; quality improvement of the services rendered by non-commercial organizations.

The network civil communities create the global crowdsourcing projects using the network cooperation technology. The successful example of the technology application is the project "My Territory" (www.Streetjournal.org), enabling the network interaction of the citizens from four countries: Belarus, Kazakhstan, Russia and Ukraine (Moya territoriya, 2014). The project is aimed at the provision of the effective interaction between the citizens of the municipal units of the regions and the representatives of the authorities for the organization of solving of local communities' problems.

The Internet-project "Demokrator" can be also mentioned as one of the most successful crowdsourcing projects (www.democrator.ru). It represents the universal and structured platform of the public and open interaction of the citizens, government authorities, local government, organizations, parties and social movements. The constructive potential of the project consists in the effective accomplishment of a wide range of tasks: provision of a universal communication platform to maintain the public open discussion of socially significant issues (crowdsourcing) by citizens and expert communities; engagement of citizens and organizations in the process of decision making by the government authorities and local government, including use of mobile devices; public monitoring of the activity of the government authorities and local government including maintenance of public estimation of the interaction between the citizens, government authorities and local government, organizations, parties and social movements. During the project implementation, the citizens have submitted nearly 6000 complaints. Over a hundred of them were satisfied: from the requirement to rename one of the streets of St.-Petersburg to rise of the wage for civil employees in the military units of the Ministry of Defence of the Russian Federation.

The crowdsourcing projects initiated from the bottom has become popular in Russia as in other states in emergencies. Thus, the summer fires which took place in the most Russian regions in 2010 showed that there is no system of the information management in the state which would allow authorities and citizens timely to make effective decisions in emergencies. The social networks and bloggers took over this function: they not only have presented people the evidence of witnesses, photos and videos of tragic events, etc., but also have elaborated online-projects by using them, enabling to coordinate the organization of the civil initiatives aimed at rendering assistance for victims. After the bloggers had discussed the possibilities of the quick help to victims in August 2010, the group of programmers (Vrazhina, 2010) was built which launched the web-site "Map of Help" 
(http://russian-fires.ru) within the shortest period. As a basis for the web-site, the adapted system "Ushahidi" was used.

The constantly running project "Virtual Rynda: the atlas of help in emergencies" (http://rynda.org/) is based on the crowdsourcing of the network users. The web-site "Virtual Rynda" was designed to coordinate mutual aid. Its goal is to show the potential of the Russian network community for the cooperation between the Internet users and different organizations, including non-commercial organizations, state and business structures. Everyone can inform on his/her trouble or desire to help. The messages are posted online and draw attention to events and problems. The gathering, analysis, processing and provision of such information assist the person who needs help as much effectively as possible to meet those who can help them.

The crowdsourcing project "Rosyama" (http://rosyama.ru/page/about/) unites the citizens who have faced the incompetence of the road services which do not fulfill their obligations. The citizens post the information on road defects on this web-site and by making official complaints to the State Traffic Safety Inspectorate (GIBDD) and the Office of Public Prosecutor of the Russian Federation and achieve that the road defects are removed.

Under the auspices of the association "Golos (Vote)", the civil project "Map of Election Breaches" was launched as a crowdsourcing resource of bottom electronic democracy. The idea of "Map of Breaches" was produced at start of the election campaign within the elections of State Duma deputies in 2011 as a joint project of "Gazeta.Ru" and the association "Golos" (http://www.kartanarusheniy.org/pages/about). As it was acknowledged in the competition "Prize of the Runet 2011", "Map of Breaches" was put in the list of twenty best web-sites in the category "State and Society". The success of the web-site and the public effect made by the Map exceeded the expectations of the idea authors, and "Map of Election Breaches" has been a constantly running Internet-resource for tracking on-line breaches since the presidential election campaign of 2012. The government responded to the actions of the civil network public community within the crowdsourcing activity and protest activity in the winter of 2011 with the project "Web-Election 2012" (webvybory2012.ru). However, the above mentioned resource did not assume the detection of breaches by the citizens online and aggregation of network resources of the public organization "League of Voters", representing the interests of the protesting electorate.

In the situation of the clash of interests of the civil public community and ruling elite, crowdsourcing becomes a mechanism of mobilization of protest actions. The aggravation of such confrontation occurred during the election cycle of 2011-2012. According to the foundation "Public Opinion", $32 \%$ of the all interviewed respondents stated on 10 July, 2012 that they were discontent and are ready to participate in protests (Fond Obshchestvennoe Mnenie, 2012). In the conditions of "narrowing" real space of the Russian public policy, crowdsourcing can contribute to the development of the alternative political projects.

It is important that the spontaneous crowdsourcing practices, developing in the network communities, are used by the different subjects of the civil society for the optimization of different horizontal network interactions in the lines "public sector - citizens", "commercial sector - citizens", "non-commercial sector - commercial sector", and "commercial sector - citizens".

The development of the competent public network based on the network interaction between non-commercial organizations and business can be exemplified by the project crowdsourcing, initiated by the autonomous non-commercial organization Agency of Strategic Initiatives (ASI) and oriented on the support of the development and implementation of the monitoring maps of the projects of the national and entrepreneurial initiative (NEI) on the improvement of the investment climate in the Russian Federation. The NEI contains the mechanism of the full-scale public discussion, functioning during all life cycle of a motoring map - from its design to the management of their introduction - using technology of crowdsourcing and attraction of businessmen to the creation of certain solutions for monitoring maps. At the first stage of the crowdsourcing activity, the Agency built the working groups for the first four projects of NEI and approved the approach to the designing of motoring maps, worked out the uniform principles, formats and methodology for the designing of motoring maps, estimated the effects from their introduction (Ekspertnaya set' po voprosam gosudarstvennogo upravleniya, 2012).

The interesting example of crowdsourcing is the project Innovation Jam by IBM company which was started in 2006. Within the framework of the project, over 150000 people from 104 countries participated in the virtual brain storming focused on new ideas search, including the formulation of the basic idea of the company ecological project. The selected proposed ideas became 10 scale projects with initial investments of 100 million US dollars. (Rumyantseva, 2009). 
The large business structures integrate the element of the cooperation with their stakeholders into the mechanisms of social investment of territories. The charity foundation of OJSC "Lukoil" and its affiliated companies in the regions where the company has carried its activity since 2002 have held the competition of crowdsourcing projects which can be initiated by the network structures of the stakeholders of OJSC "Lukoil" (local community, institutions of education and culture, non-commercial organizations, public associations, and mass media of the regions of Lukoil activity). For 10 years of competition holding, over 9000 applications have been submitted, over 2000 of them have been implemented as projects (Lukoil obyavil pobediteley konkursa..., 2012).

The network interaction of the actors of the civil structures is not "frozen" upon the achievement of the crowdsourcing activity purposes, and is continued within other network practice and projects, fixing non-commercial innovations in the institutional environment of public policy. For example, the foundation "Skolkovo" together with the foundation "Public Opinion" launched the project crowdsourcing "On the Sense of Innovations: Collective Book: Discussion, Preparation, and Implementation". Besides the design of the intellectual innovative product, the project involves the selection of the innovators from the social environment. As the moderators of the electronic resource say, the most topical innovative ideas of the network community members will be supported by the foundation "Skolkovo" (O smysle innovatsiy..., 2012).

The lawmaking crowdsourcing, based on the technology of network brainstorming, represents the collective activity of citizens on the initiation and working out of the regulatory legal acts of any level, from the constitution drafts to local rules. For example, the financial crisis in Iceland provoked under the impact of the global events in 2008 the large civil protests requiring to rewrite the constitution which was adopted in 1944 when the country gained the independence from Denmark. Since November 2011, the network community was engaged in the drafting of the constitution text on several communication online-platforms - the site of the Constitutional Council which was elected during the public referendum (http://stjornlagarad.is/) and on the network service Facebook (http://www.facebook.com/Stjornlagarad) (Islandiya predstavila konstitutsiyu..., 2011). Thus, the crowdsourcing draft of the constitution allowed to solve two political problems of Iceland; on the one hand, the government shared the political risks of the drafting and approval of the new constitution with the citizens who took part in the writing of the rules of their own life; on the other hand, the government multiplied the rate of the people who are loyal to its activity because the majority of the citizens realized that their opinions are significant.

In Great Britain, the integrated crowdsourcing platform Jolitics.com was created by Michael Birch, the founder of the social network, for the optimization of the lawmaking activity by the political activists and the lobby representatives. (Tyler, 2011). The resource imitates is a model of the British parliament work, involving the stages of project introduction, its discussion and voting. At first, the platform enabled to make only proposals in the nation-wide policy, but later it was planned to discuss also the issues of the local level using it.

The users of Jolitics can post on the web-site their proposals (analogue of a draft law) of not more than 140 symbols (similar to the micro-blogging in Twitter) and its brief description. The rest of the users can discuss the "legislative" initiative within four weeks, and then it is put up for voting. If the proposal is approved by over $50 \%$ of the voting users, it can be sent to a member of the Parliament mentioning the number of the users who votes for it.

Crowdsourcing has been introduced into the activity of electronic governments of some states for the organization of the permanent network cooperation of the authorities and the civil society in the regionsрегионах/municipal units. So, the USA crowdsourcing projects are joined by the resource "Center for New Media and the Citizen Engagement" (http:// www.howto.gov/) which keeps the timeline of the main events the world gov 2.0 and has the guide of design, planning and implementation of network civil projects directed on the effective interaction with the authorities at federal, regional and local levels. However, the research findings show the opinions of the future participants of the communities are considered rather formally at the design stage during the design of the electronic democracy projects. If the citizens are involved in the implementation of the projects at early stages, the chances to create sustainably and effectively functioning virtual network communities are much multiplied. (Bondarenko, 2004).

In Russia, the idea to use crowdsourcing in the public practice was produced by the political leaders of the country and became the continuation of social network popularization. At that time, the President of the Russian Federation was D. A. Medvedev. In spring 2010, the specialized social network "Regionalochka" (http://regionalochka.ru/) was launched for the officials who are responsible for "informatization, administrative reform and shift to the rendering of state and municipal services online" under the initiative of the Ministry of 
Communications and Mass Media. The mentioned crowdsourcing project has had the aim to form the network community of IT-professionals in the state and municipal management and their effective information interaction.

In June 2011, the social network "GosBook" (http://www.gosbook.ru/) has started functioning for the Russian officials and experts, who are "ready and capable to participate in the subject discussion on topical issues of the Russian society" within the framework of the state programme of the Russian Federation "Information Society (2011-2020)" on the initiative of the Administration of the President of the Russian Federation. "GosBook" was designed by the presidential Academy of Public Administration of the Russian Federation, Governmental Academy of National Economy of the Russian Federation, Higher School of Economics, Institute of Contemporary Development, and the autonomous non-commercial organization "Group for Project Design "Informekspertiza" (Agopov, 2012).

The absolute advantage of the crowdsourcing project "GosBook" is an opportunity for the officials of the different levels and management to create expert and task groups for the discussion of the topical issues of the public administration, e.g., legislative initiatives, standard acts under development, and the drafts of concepts. In 2013, the project united 31 expert network communities conducting the network brainstorming on the topical directions of the state policy of the Russian Federation. Any user can take part in the discussion of the acute topics of the expert communities: from the representatives of business and non-commercial organizations to the common citizens.

The online-platform of public expertise and updating of the Law "On Education" (http://edu.crowdexpert.ru/) started on 1 June, 2010 has become a pilot crowdsourcing in the Russian lawmaking activity. The crowdsourcing resource created the conditions for the development of the open public network for the experts of different categories: teachers and workers of education area, scientists, parents and the representatives of profile public organizations. The methodical organization of public expertise proposed the free access to the text of the law for all interested persons and its further commenting and editing by registration and filling in of a special profile. Then, the effective network experts were selected and admitted to the official group of experts who had taken part in the traditional lawmaking process (Burov, 2011).

The trend of the public discussion of draft laws by crowdsourcing was adopted by the Decree of the President of the Russian Federation "On Public Discussion of the Drafts of Federal Constitutional Laws and Federal Laws" in February 2011, and the opportunity of national commenting of the draft laws on the web-site "Public Discussion of Laws" (http://zakonoproekt2012.ru/) has been provided since 1 June, 2011. In such a way, the amendments for the federal law "On the Civic Chamber" were prepared, the essence of which was reduced to the granting of an opportunity to the citizens to propose the legislative initiatives to the State Duma of the Federal Assembly of the Russian Federation, if they are supported by 10000 Russian citizens (The Civic Chamber of the Russian Federation: an official site).

Similarly to "Demokrator", the Government initiated the creation of the crowdsourcing online-platform "Integrated Portal of Electronic Democracy of the Russian Federation" (http://e-democratia.ru/) under the order of the Ministry of Communications and Mass Media of the Russian Federation. The platform was presented on 18 May, 2012 on the first Federal Congress of Electronic Democracy.

\section{Socio-Political Role of Crowdsourcing Activity}

Political crowdsourcing as an interactive mechanism of the public policy development combines the set of forms and technologies of the public participation of citizens in the public policy, based on the collective production of socio-political ideas and political practices. In such a way, crowdsourcing facilitates the initiation and introduction of the political innovations considered as a directed change of the particular characteristics of the political system - political institutes or political processes - with the purpose to improve their activity efficiency. In this case, crowdsourcing process, using T. F. Gareev's terminology (Gareev, 2006), is understood as a dynamical and positively estimated interaction between innovators and the external political environment that is a result of the changes of the public policy or its part accomplished intentionally by an innovator with the application of new knowledge or the knowledge, not have been used before in this area. A. Yu. Sungurov thinks that the stimulation of the various crowdsourcing activity forms in the public policy promotes the permanent application of innovations which have characteristics of the public goods (Sungurov, 2011).

The final result of the crowdsourcing activity in the public policy is institutional political innovations used by the citizens in their political practices. Their high speed of the dissemination in the public policy is explained by that as E. Rogers insists, the motive power of innovation diffusion is the interpersonal dialogue between the representatives of social groups (Rogers, 1995). 
Crowdsourcing cannot exist outside the network communities which produce political innovations and act as agents of their distribution in the political environment at the same time. The institutional "rooting" of the crowdsourcing activity results occurs through social training during which the normative and analytical attitudes of the participants of the particular practice formation change.

Crowdsourcing activity enables the evolutional extension and complication of public policy by political training of the citizens participating in it. Originally, the micro-changes take place which do not touch upon the normative and analytical principles of individual political practices. At the second level, the search for the crowdsourcing tools of the problem solving begins because of the growing inefficiency of common political practice, but this search of new optimal solutions is performed within the strictly prescribed and permanent framework of priorities and expectations (Klitsunova, 2004). At the third level, the institutional changes and the change of policy paradigms occur; traditional ideas and routine methods give way to new ideas and non-standard solutions.

So, crowdsourcing in public policy solves several important problems at the same time. First, it contributes to the consolidation and activation of a network civil society in the solving of really existing social problems that entails the transformation of principles of effective interaction between the authorities and institutes of the civil society. It is worth to agree with the predictions of the German analysts about that the crowdsourcing toolkit allows the qualified and politically thinking citizens standing apart traditional parties much more actively to join the political process. Instead of a classical "letter of the reader" or an application to a deputy, the citizens have an opportunity to intervene directly in decision-making process - more often on quite certain topic, quickly and orderly (Bohnen \& Kallmorgen, 2009). Secondly, the important task of crowdsourcing within public policy is the initiation and introduction of the innovations in the system of political management. Crowdsourcing enables the members of social networks to integrate into the expert political community and design the innovative projects, aiming not only at the distribution of effective administration practice expert, but also the modernization of the particular spheres of the human life activity.

Crowdsourcing have not widely been used in the activity of traditional political parties yet which this technology could help to find new forms of the interaction with citizens (The blog about technologies from BBC News, 2014) (Berry, 2010). To the contrary, anti-establishment and hybrid parties (such as Five Stars Movement in Italy, UKIP in Great Britain and many pirate parties) widely use the crowdsourcing technologies for the mobilization of their electorate.

As the analysis of generalized practices of the application of crowdsourcing activity technologies in the Russian public policy shows that crowdsourcing is the most actively used in the non-commercial sector. The effective practices quite quickly are adapted by the public administration authorities of the different levels. The non-commercial crowdsourcing projects, interacting with each other and being deeply intertwined with the electronic government structures, form an integrated ecosystem of the electronic democracy in the Russian public policy. Crowdsourcing activity facilitates the consolidation of a new model of the civil society. It is worth to be mentioned that its essence consists not only in the maximum contributions of the actors but also in their political participation. Saying in the other words the idea by C. Pateman, it is also possible to apply political solutions in the "development of social and political opportunities of each individual that provides the feedback between the contribution and result" (Pateman, 2006).

The evolutionary potential of the development of the public policy system in modern Russia resides in political innovations which arise from crowdsourcing activity. The political will of the state government to the reengineering of the administration approaches and change of the public policy system plays an important role in the diffusion of the Russian political innovations. If a state does not integrate the innovations of public networks into the public administration system and does not use the network management potential for the improvement of efficiency of its capabilities, crowdsourcing becomes a mechanism of the citizens' political mobilization which has a protest but not constructive nature.

\section{Conclusions}

Crowdsourcing as a kind of socio-political activity has been widely distributed in the modern public policy. Prediction market, crowdcasting, network brainstorming, project crowdsourcing, and crowdfunding became its basic technologies. The authorities, non-commercial organizations, business structures and network communities, introducing different crowdsourcing technologies into their public activity practice, act as the subjects of the political crowdsourcing.

The government authorities are oriented in a greater degree on the creation of information online-platforms, combining the technologies of crowdsourcing and project crowdsourcing. The mechanisms of network 
brainstorming for political expertise of the decisions from the different areas of the state policy within the electronic government system and the system of public lawmaking crowdsourcing have been designed.

At the same time, crowdsourcing activity within the structure of the electronic government originates from a source area despite of the pro-active attitude of the political government to the introduction of principles and mechanisms of electronic democracy stated in the statism discourse of the program documents on the Russian Federation modernization. The governmental crowdsourcing is effective only when it is integrated into the structures of the civil society, being agents of the diffusion of the political innovations in the Russian public policy. The "dead" crowdsourcing projects have been network communities which were created in an artificial way by the officials, e.g., "GosBook". The positions of the political parties as subjects of political crowdsourcing are weak enough and differentiated.

The institutes of the civil society more widely use the crowdsourcing innovative potential in the public practice, relying on the different technologies: political prediction market, network brainstorming, crowdcasting, and project crowdsourcing. Crowdsourcing activity not only enables the creation of constantly running public networks in the certain segment of public policy, but also provides the basis for the institutionalization of the internetwork cooperation between non-commercial organizations, mass media, business structures and citizens. Not to stay on the periphery of public policy, the government authorities have to accept the rules of a new game, determined as a result of internetwork cooperation between the social subjects of politics.

The important tendency of crowdsourcing consolidation as an innovative activity in the Russian public policy dissemination of the culture of electronic democracy by informal leaders of the network community - takes place. They introduce the crowdsourcing standards by means of social training and stimulation of network public community activity by competitions, actualizing political practices of crowdsourcing both within territorial communities and national state.

If the actualization of the interests of the network civil society in sphere of public policy is not reflected in the various forms of the cooperation with the government authorities, they get protest forms of the network community mobilization and institutionalized as alternative structures of electronic democracy as in the case of "League of Voters".

Generally, the crowdsourcing activity in the Russian public policy is based on the different technological approaches which also exist in foreign countries. The network structures aspire to create the ecosystem of the electronic democracy which will be based on the crowdsourcing technologies. However, there are institutional restrictions of the implementation of the mentioned prospect, dealing with imitating publicity of authorities' practice in Russia: as soon as the motive powers of the network public communities shift their activity focus from the certain problems on the legitimacy of the political regime, they face the counteraction of the government authorities at once. At the same time, the supporting of any crowdsourcing form as an interactive mechanism of public policy development oriented on the cooperation of political subjects or their opposition facilitates the development of the network public policy.

\section{References}

To create one more bee that will work against honey is ineffectively. (2011, October 12). Kommersant.ru. Retrieved from http://www.kommersant.ru/doc/1793305

"Ushahidi" rescues people. Now in Russia. (2010, August 6). New newspaper. Retrieved from http://www.novayagazeta.ru/ society/2340.html

Agopov, I. (2012, June 18). One more network "Gosbook" will create for officials besides "Regionalochka". Business newspaper "Marker". Retrieved from http://www.marker.ru/news/459

Asmolov, G. (2014). Virtual Rynda - The atlas of help: mutual aid as a form of social activism. Crowdsourcing in transition from emergency to everyday life. Retrieved from http://book.globaldigitalactivism.org/chapter/ virtual-rynda-the-atlas-of-help-mutual-aid-as-a-form-of-social-activism/

Berry, D. (2010, November 17). Political crowdsourcing: The Alberta Party attempts to change the process. VUE WEEKLY.

Bevir, M., Rhodes, R. A. W., \& Weller, P. (2003). Traditions of governance: Interpreting the changing role of the public sector. Public Administration, 81. http://dx.doi.org/10.1111/1467-9299.00334

Bohnen, J., \& Kallmorgen, Ja.-F. (2009, October 23). As Web 2.0 changes policy. Internationale Politik, Retrieved from http://www.germania-online.ru/publikacii/ip/ip-detail/datum/2009/11/23/kak-web-20-izme njaet-politiku.html 
Bondarenko, S. V. (2004). Social technologies of "electronic democracy" (attempt of construct verification). Theory and practice of public and scientific information, 19, 171-196.

Brabham, D. (2008). Crowdsourcing as a model for problem solving: an introduction and cases. Convergence: The International Journal of Research into New Media Technological Studies, 14(1), 75-90.

Burov, V. V. (2011). Application of crowdsourcing technology in legislative activity. Business computing, (2), $12-20$.

Castells, M. (1999). Stanovlenie obshchestva setevykh struktur. In V. L. Inozemtsev (Ed.), Development of society of network structures. New post-industrial wave in the West: anthology. Moscow: Academia.

Castells, M. (2000). Information era: economy, society, and culture. Moscow: Higher School of Economics Publ.

Crowdsourcing. (2014). Material from Wikipedia - the free encyclopedia. Retrieved from http://ru.wikipedia.org/ wiki/Crowdsourcing.

Damgaard, B. R. (2005). Do policy networks lead to network governing? Welfare Systems and Policies Working Paper, 3.

Expert network of public administration. (2012). The report on the designing of the monitoring maps of projects within the national enterprise initiative for the improvement of the investment climate in the Russian Federation - results of the 1 qtr. of 2012. Retrieved from http://www.gosbook.ru/node/55410

Fukuyama, F. (2008). Trust: social virtues and the way to prosperity: translated from English. Moscow: AST.

Gareev, T. F. (2006). Evolution of innovative process models. Bulletin of TISBI, (2), 24-32. Retrieved from http://old.tisbi.org/ science/vestnik/2006/issue2/econom4.html

Geerts, S. (2009). Discovering crowdsourcing. Theory, classification and directions for use. Eindhoven: Eindhoven Technical University Publ.

Goodwin, J. (2010, August 12). Integrating social networks onto GIS maps for emergency planners. Government Security News. Retrieved from http://www.gsnmagazine.com/node/21218

Hacker, K. L., \& Dijk, J.van. (2000). Digital democracy. Issues of theory \& practice. London: Sage publications. http://dx.doi.org/10.4135/9781446218891

Howe, J. (2012). Crowdsourcing: collective mind as an instrument of business development: translated from English. Moscow: Al'pina Pablisher.

Iceland has presented the constitution written by crowdsourcing. (2011, July 30). Habrahabr. Retrieved from http://habrahabr.ru/blogs/crowdsourcing/125264/

Klijn, E.-H., \& Koppenjan, J. F. M. (2000). Public management and Policy Networks. Foundations of a Network Approach to Governance. Public Management, 2(2), 135-158. http://dx.doi.org/10.1080/146166700411201

Klitsunova, E. V. (2004). Factories of ideas and political transfer. In A. Yu. Sungurov (Ed.), Public policy-2004 (p. 37). St. Petersburg: Norma.

Krasnodar citizen plans to start campaign against "rams" on roads by means of a crowdfunding. (2014, July 30). Yugopolis. Retrieved from http://www.yugopolis.ru/news/auto/2014/07/30/71329/dorojnoe-dvijenie-ilyafeigenov

Lukoil announced the winners' names of competition of social and cultural projects. (2012, June 15). Agency of Social Information. Retrieved from http://www.asi.org.ru/asi3/rws_asi.nsf/va_WebPages/89F05CF86EEE 7C8344257A1E003A8B41Rus

Miroshnichenko, I. V. (2011). Modernization potential of crowdsourcing in modern public policy. Problem analysis and state and administrative designing, 4(6), 31-39.

Miroshnichenko, I. V. (2012). Crowdsourcing activity in public policy: New opportunities of the civil society. Political examinationvexpertize: POLITEKS, 8(3), 150-158.

Morozova, E. V., \& Miroshnichenko, I. V. (2009). "Investors of the political capital": Social networks in political space of the region. Political researches studies, (2), 76-92.

My territory. Retrieved from http://www.streetjournal.org/

On the sense of innovations: collective book: Discussion, preparation, and implementation. (2012, January 13). Innovations and society. Retrieved from http://innov.fom.ru/site1/ book/node/complex/271 
Pateman, C. (2006). Mass participation and theory of democracy. In Theory and practice of democracy: selected texts (pp. 35-36). Moscow: Ladomir.

Patrushev, S. V. (2009). Civil engagement: Institutional approach (research prospects). Political research studies, (6), 24-32.

Pierre, J. (2000). Debating governance. Oxford: Oxford University Press.

Public Opinion Foundation. (2012). Level of protest mood. Opinion poll "FOMnibus" on 9-10 June. 100 settlements, 43 territorial subjects of the Russian Federation, 1500 respondents. Retrieved from http://bd.fom.ru/pdf/d23ypn12.pdf

Puthnam, R. (1996). In order that the democracy works: civil traditions in modern Italy. Moscow: Ad Marginem.

Rogers, E. M. (1995). Diffusion of innovations (4th ed.). New York: The Free Press.

Rose, R. (2002). Achievement of the objectives in the quasi-modern society: Social networks in Russia. Social sciences and the present, (3), 23-65.

Rumyantseva, I. (2009). Crowdsourcing and social development of the society. Social policy and social partnership, (8), 43.

Ryabchenko, N. A. (2012). Institutionalization of the public policy on the Internet in modern Russia: stages, actors, and technologies (Dissertation of Candidate of Sciences). Krasnodar.

Sungurov, A. Yu. (2011). Innovations and environment: on the way to political innovations: textbook. St. Petersburg: Higher School of Economics, National Research University Publ.

The blog about technologies from BBC News. (2014). Retrieved from http://www.bbc.co.uk/blogs/legacy/ technology/rory_cellanjones/

The Civic Chamber of the Russian Federation: official web-site. Retrieved from http://www.oprf.ru/

Tyler, R. (2011, March 21). Jolitics: Bebo founder's political social network launches. The Telegraph. Retrieved from http://www.telegraph.co.uk/technology/social-media/8394883/Jolitics-Bebo-founders-political-socialnetwork-launches.html

Vrazhina, A. (2010, August 5). Fire situation. Lenta.ru. Retrieved from http://lenta.ru/columns/2010/08/05/fires/

Wexler, M. (2011). Reconfiguring the sociology of the crowd: Exploring crowdsourcing. International Journal of Sociology and Social Policy, 31(1/2), 6-20. http://dx.doi.org/10.1108/01443331111104779

\section{Copyrights}

Copyright for this article is retained by the author(s), with first publication rights granted to the journal.

This is an open-access article distributed under the terms and conditions of the Creative Commons Attribution license (http://creativecommons.org/licenses/by/3.0/) 